Specijalna edukacija i rehabilitacija

(Beograd), Vol. 12, br. 3. 275-289, 2013.
UDK: 376.1-056.263-053.4/.5 ;

81'234-056.263-053.2

ID: 201312524

Originalni naučni rad

doi: $10.5937 /$ specedreh12-4118

Sanja ĐOKOVIĆ ${ }^{1 *}$

Selena TODOROVIĆ**

University of Belgrade

Faculty of Special Education and Rehabilitation*

Institute for Experimental Phonetics and Speech Pathology**

\title{
INFLUENCE OF HEARING AGE AND UNDERSTANDING VERBAL INSTRUCTIONS IN CHILDREN WITH COCHLEAR IMPLANTS ${ }^{2}$
}

Hearing age is defined as a period of using any amplification. Most researches indicate that hearing age influences the developmental rate of auditory and speech-language abilities in deaf children, especially when cochlear implantation was performed before the age of three. This research is aimed at analyzing the influence of hearing age on understanding verbal instructions in children with cochlear implants. The sample consists of 23 children with cochlear implants and 21 children with normal hearing, aged between 4 and 10. Hearing age of children with cochlear implants was between 2 and 7 years. Token Test with toys, adapted for children with hearing impairments, was used to analyze understanding verbal instructions. The results indicate that there are statistically significant differences between children with cochlear implants and children with normal hearing, aged between 4 and 7 , on all subtests and the total score regardless of the hearing age (sub1 $p<0.001$, sub2 $p<0.000$, sub3 $p<0.001$, total score $p<0.000$ ). No statistically significant differences were determined on any of the subtests in children aged between 7.1 and 10 , regardless of the hearing age. Comparative results analysis within the experimental group of

1 E-mail: sanjadjokovic64@gmail.com

2 The paper is a result of the project: Influence of Cochlear Implantation on the Education of Deaf and Hard of Hearing People, number 179055 (2011-2014), financed by the Ministry of Education, Science and Technological Development of the Republic of Serbia 
Specijalna edukacija i rehabilitacija (Beograd), Vol. 12, br. 3. 275-289, 2013.

children with different hearing age indicates that the difference in understanding verbal instructions between these two groups is not statistically significant.

Key words: cochlear implant, hearing age, understanding

\section{INTRODUCTION}

Cochlear implant (CI), as well as the interest in it, has been developing for over 50 years. Djourno and Eyriès performed first cochlear implantation in 1957 (Niparko, 1998). First patients were adults with post lingual hearing impairment. Since then, age limit for cochlear implantation has moved significantly toward younger population, because numerous studies indicated a positive influence of early implantation on gaining complex auditory skills and speechlanguage abilities (McConkey at al., 2004).

Cochlear implant is a modern aid which significantly improves auditory abilities in children and eases the process of speech-language rehabilitation. With cochlear implant, children with severe hearing impairment communicate much more efficiently using speech. However, this hearing aid is not equally successful for all its users. Research on these variables in the results of using cochlear implants is one of the central research topics in surdology. Nowadays, many people are trying to explain individual differences focusing on medical, demographic or education variables. Although these factors influence the differences in CI results, they are not the only ones. Recent studies have shown that learning, memory, attention, and cognitive control have an important role in the differences of CI results (Pisoni et al., 2008).

The most frequently studied factors which influence CI results are: length of deafness, implantation age, critical period, i.e. time period from the moment when hearing impairment was diagnosed until the beginning of rehabilitation period, hearing age, means of communication, and educational environment and intellectual abilities.

Hearing age represents time period of using cochlear implant, which may influence the formation of auditory and speech-language abilities in deaf children, especially if cochlear implantation was performed before the age of three when brain plasticity is the highest (Cirk et al., 2002; Miyamoto et al., 2003; Ostojić et al.,2011; Mikić et al., 2008; 
Đoković, S., Todorović, S.: Influence of hearing age and understanding verbal instructions in children with cochlear implants

Đoković et al., 2010). Most CI children achieve good results in the tasks of recognizing open word groups after one year of using CI (Eisenberg et al., 2008), and this ability continues to develop together with the hearing age (Miyamoto et al., 1996; Fryauf et al., 1997). After two years of using CI, deaf children catch up with their hearing peers in lexis if the implantation was performed before 30 months of age (Connor et al., 2006).

Longitudinal studies have shown that 10 year usage of cochlear implant leads to better understanding of speech in quiet and noisy environments. About $80 \%$ of $C I$ children understand a voice message in a quiet environment, and $44 \%$ in a noisy environment (Uziel et al., 2007). Speech of CI children is comprehensible for $40 \%$ of people who know that they have CI, and $27 \%$ of people understand their speech not knowing they are deaf (Uziel et al., 2007). Hearing age leads to the point when children can understand speech without reading from lips, and their speech is very comprehensible (Beadle et al., 2005).

Children with hearing impairment fall behind in auditory and speech-language abilities, but overcome this after cochlear implantation (Ostojić et al., 2007, Mikić et al., 2008). They successfully develop receptive and expressive speech to an average level for their age if the implantation is performed timely (Svirsky et al., 2004). The explanation of these results lies in the fact that children implanted at an early age have a shorter period of auditory deprivation and longer hearing experience (longer hearing age) than those implanted later.

Plant and Moor decidedly insist in their research that hearing and chronological age influence the understanding of verbal instructions in CI children. While working on adapting and validating TTI test, they performed a pilot research which indicates that hearing and chronological age have a statistically significant influence on the results of understanding verbal instructions in CI children, both on the subtest and total score levels (Plant \& Moor, 1992).

It is very important to mention research results of Deborah James et al. which indicate that intensive progress in auditory and speechlanguage abilities in CI children occurs in the first four years of using cochlear implants, and that, after that period, there is a significant slowdown in progress, especially in receptive speech (James et al., 2007). It is also emphasized that there are great and functionally 
Specijalna edukacija i rehabilitacija (Beograd), Vol. 12, br. 3. 275-289, 2013.

significant variations in auditory and speech-language results of CI children (James et al., 2007).

In his research, Dowell (Dowell et al., 2002) more precisely defined the influence of hearing age on auditory perception of certain speech segments. He emphasizes that hearing age influences the perception and identification of phonemes and words, but not the perception and understanding of sentences. Also, this research confirms that intensive changes in perceptive abilities should be expected in the first three years of cochlear implantation, and that there is a gradual slowdown and decrease in the growth rate of the progress effects with the increase in the hearing age (Dowell et al., 2002).

\section{THE METHOD}

\section{Participants}

The sample consists of 44 children of both genders, out of which 21 hearing (47.7\%) and 23 with cochlear implants (52.2\%). The sample was divided into two groups with regard to the chronological age: from 4 to 7 , with 14 hearing (31.8\%) and 12 deaf children (27.2\%), and from 7.1 to 10 , with 7 hearing (15.9\%) and 11 deaf children (34\%) (Table 1). Table 1 - Sample with regard to hearing age

\begin{tabular}{ccccccc}
\hline \multicolumn{7}{c}{ Age } \\
\hline & \multicolumn{1}{c}{4 to 7} & $\mathrm{~N}$ & \multicolumn{1}{c}{ to 10} & \multicolumn{2}{c}{ Total } \\
\hline & $\mathrm{N}$ & $\%$ & $\mathrm{~N}$ & $\%$ & $\mathrm{~N}$ & $\%$ \\
\hline Hearing children & 14 & 31.8 & 7 & 15.9 & 21 & 47.7 \\
\hline CI children & 12 & 27.2 & 11 & 34 & 23 & 52.2 \\
\hline
\end{tabular}

Within its age subgroups, the experimental group was divided according to hearing age as follows: age group from 4 to 7 was divided into two groups of hearing age - from 0 to 2, and from 2.1 to 4 , each with $6 \mathrm{CI}$ children. Apart from the above mentioned hearing ages, the age group from 7.1 to 10 also included the group from 4.1 to 7 . There were $2 \mathrm{CI}$ children in the group from 0 to 2 years, $3 \mathrm{CI}$ children in the group from 2.1 to 4 , and $6 \mathrm{CI}$ children in the group from 4.1 to 7 years. All had average intellectual abilities, and no additional impairments (Table 2).

Average hearing age of CI children in the age group from 4 to 7 years is 2.2 years, and in the group from 7.1 to 10 years is 4.3 years. 
Đoković, S., Todorović, S.: Influence of hearing age and understanding verbal instructions in children with cochlear implants

Table 2 - CI children with regard to hearing age

\begin{tabular}{ccccccccc}
\hline \multicolumn{10}{c}{ Hearing age } \\
\hline & 0 to 2 & \multicolumn{2}{c}{2.1 to 4} & \multicolumn{2}{c}{4.1 to 7} & \multicolumn{2}{c}{ Total } \\
\hline & $\mathrm{N}$ & $\%$ & $\mathrm{~N}$ & $\%$ & $\mathrm{~N}$ & $\%$ & $\mathrm{~N}$ & $\%$ \\
\hline 4 to 7 & 6 & 26 & 6 & 26 & 0 & 0 & 12 & 52.1 \\
\hline 7.1 to 10 & 2 & 8.6 & 3 & 13 & 6 & 26 & 11 & 47.8 \\
\hline
\end{tabular}

\section{Instruments}

Token Test with toys (TTI) (Plant \& Moor, 1992) was used, which was adapted for younger children with hearing impairment and has two versions. A shorter version is used in younger preschool children and consists of 3 levels and 30 verbal instructions. A longer version is used in younger school children and has 6 levels with 60 verbal instructions. Verbal instructions are arranged from simple „Show a green boat”, or „Take a red car”, to complex ones „Take a red car and put it in a red circle”, „Take a green helicopter and put it in a blue circle”. The materials used for testing are also adapted to age.

All children were individually tested, with no time limits, and in appropriate quiet space (minimal ambient noise). The task was to listen to the instruction carefully and perform it. One point was awarded for each successfully performed instruction.

\section{Data Analysis}

Central tendency measures, variability measures and results range (minimum and maximum) were used to show basic statistical parameters. Variance analysis (ANOVA) was used to determine the significance of relations between independent and dependent variables.

\section{RESEARCH RESULTS AND DISCUSSION}

For the purpose of better interpretation, the results are presented within two age groups: from 4 to 7 and from 7.1 to 10 years of age. Also, it should be emphasized that a shorter version of TTI was used for younger children, i.e. they were tested only with the first three subtests, while older children were tested with the complete test of 6 subtests. 
Specijalna edukacija i rehabilitacija (Beograd), Vol. 12, br. 3. 275-289, 2013.

Table 3 - Descriptive parameters on tasks of understanding verbal instructions in children aged between 4 and 7

\begin{tabular}{ccccccc}
\hline & & $\mathrm{N}$ & Min & Max & AM & SD \\
\hline \multirow{2}{*}{ sub1 } & hearing & 14 & 10 & 10 & 10.00 & 0.00 \\
\cline { 2 - 7 } CI & $2.1-4$ & 6 & 4 & 10 & 8.50 & 2.34 \\
\cline { 2 - 7 } CI & $0-2$ & 6 & 1 & 10 & 5.67 & 3.83 \\
\hline sub2 & hearing & 14 & 10 & 10 & 10.00 & 0.00 \\
\cline { 2 - 7 } CI & $2.1-4$ & 6 & 1 & 10 & 5.83 & 3.97 \\
\cline { 2 - 7 } CI & $0-2$ & 6 & 0 & 8 & 3.50 & 3.98 \\
\hline sub3 & hearing & 14 & 10 & 10 & 10.00 & 0.00 \\
\cline { 2 - 7 } CI & $2.1-4$ & 6 & 1 & 10 & 8.00 & 3.52 \\
\cline { 2 - 7 } CI & $0-2$ & 6 & 0 & 10 & 4.33 & 4.76 \\
\hline Score & hearing & 14 & 30 & 30 & 30.00 & 0.00 \\
\cline { 2 - 7 } CI & $2.1-4$ & 6 & 6 & 30 & 23.33 & 9.18 \\
\cline { 2 - 7 } CI & $0-2$ & 6 & 1 & 28 & 13.50 & 11.43 \\
\hline Success $\%$ & hearing & 14 & 100.00 & 100.00 & 100.00 & 0.00 \\
\cline { 2 - 7 } CI & $2.1-4$ & 6 & 20.00 & 100.00 & 74.44 & 30.59 \\
\cline { 2 - 7 } CI & $0-2$ & 6 & 3.33 & 93.33 & 45.00 & 38.10 \\
\hline
\end{tabular}

Table 3 shows the results of understanding verbal instructions in $\mathrm{CI}$ and hearing children aged between 4 and 7. CI children were divided into two groups with regard to the hearing age: from 0 to 2 , and from 2.1 to 4 . Hearing children achieved maximum score of 10 points per test on all subtests. The total score of every hearing child was 30 points and their achievement on TTI test was $100 \%$ (Table 3 ).

CI children with hearing age from 0 to 2 achieved the best result on subtest 1 , with the average score of 5.67 , while their worst score was on subtest 2 with 3.50 points. The total score of this group of $C I$ children was 13.50 points, which is $45 \%$ of successfully completed verbal instruction tasks. The best average score of CI children with hearing age from 2.1 to 4 was on subtest 1 with 8.50 points, and the worst was on subtest 2 with the average score of 5.83. The total score of this group was 23.33 points, i.e. $74.44 \%$. Regardless of the hearing age, CI children are very heterogeneous in the achieved results on TTI test, which can be seen from minimum and maximum scores ranging from 0 to 10 on certain tests. This particularly concerns CI children with the hearing age from 0.1 to 2 (Table 3). The minimum result in CI children with hearing age from 2.1 to 4 was 6 and maximum 30, while the minimum result in $\mathrm{CI}$ children with hearing age from 0.1 to 2 was 1 and maximum 28 points (Table 3 ). 
Đoković, S., Todorović, S.: Influence of hearing age and understanding verbal instructions in children with cochlear implants

Table 4 - Results of understanding verbal instructions in hearing and CI children (aged between 4 and 7)

\begin{tabular}{cccc}
\hline & AM & $\mathrm{F}(2)$ & $\mathrm{p}$ \\
\hline Subtest 1 & 39.52 & 9.016 & 0.001 \\
\hline Subtest 2 & 100.064 & 14.536 & 0.000 \\
\hline Subtest 3 & 67.64 & 8.873 & 0.001 \\
\hline Score & 588.75 & 12.599 & 0.000 \\
\hline
\end{tabular}

The relation between the results of understanding verbal instructions in CI children of different hearing age and hearing children (chronological age between 4 and 7) was determined by means of variance analysis. The results show that there are statistically significant differences between $C I$ and hearing children regardless of the hearing age. This is noticeable on all the subtests (subtest $1 \mathrm{p}=0.001$; subtest $2 \mathrm{p}=0.000$; subtest $3 \mathrm{p}=0.001)$ and in the total score $(\mathrm{p}=0.000)$. These results indicate that regardless of whether deaf children have used cochlear implant shorter or longer than 2 years, their results on TTI test are statistically significantly worse than the results of hearing children aged between 4 and 7 (Table 4).

Table 5 - Descriptive parameters on tasks of understanding verbal instructions in children aged between 7.1 and 10

\begin{tabular}{ccccccc}
\hline & & N & Min & Max & AM & SD \\
\hline Subtest 1 & hearing & 7 & 10 & 10 & 10.00 & 0.00 \\
\cline { 2 - 6 } CI & $4.1-7$ & 6 & 10 & 10 & 10.00 & 0.00 \\
\cline { 2 - 6 } CI & $2.1-4$ & 3 & 10 & 10 & 10.00 & 0.00 \\
\cline { 2 - 6 } CI & $0-2$ & 2 & 10 & 10 & 10.00 & 0.00 \\
\hline Subtest 2 & hearing & 7 & 10 & 10 & 10.00 & 0.00 \\
\cline { 2 - 6 } CI & $4.1-7$ & 6 & 5 & 10 & 8.83 & 2.04 \\
\cline { 2 - 6 } CI & $2.1-4$ & 3 & 10 & 10 & 10.00 & 0.00 \\
\cline { 2 - 6 } CI & $0-2$ & 2 & 7 & 10 & 8.50 & 2.12 \\
\hline Subtest 3 & hearing & 7 & 10 & 10 & 10.00 & 0.00 \\
\cline { 2 - 6 } CI & $4.1-7$ & 6 & 2 & 10 & 8.50 & 3.20 \\
\cline { 2 - 6 } CI & $2.1-4$ & 3 & 9 & 10 & 9.67 & 0.57 \\
\cline { 2 - 6 } CI & $0-2$ & 2 & 7 & 10 & 8.50 & 2.12 \\
\hline Subtest 4 & hearing & 7 & 10 & 10 & 10.00 & 0.00 \\
\cline { 2 - 6 } CI & $4.1-7$ & 6 & 0 & 10 & 8.17 & 4.02 \\
\cline { 2 - 6 } CI & $2.1-4$ & 3 & 7 & 10 & 8.33 & 1.52 \\
\cline { 2 - 6 } CI & $0-2$ & 2 & 6 & 10 & 8.00 & 2.82 \\
\hline
\end{tabular}


Specijalna edukacija i rehabilitacija (Beograd), Vol. 12, br. 3. 275-289, 2013.

\begin{tabular}{rcccccc}
\hline & \multicolumn{1}{c}{ N } & Min & Max & AM & SD \\
\hline Subtest 5 & hearing & 7 & 10 & 10 & 10.00 & 0.00 \\
\cline { 2 - 7 } CI & $4.1-7$ & 6 & 0 & 10 & 8.00 & 3.95 \\
\cline { 2 - 7 } CI & $2.1-4$ & 3 & 7 & 10 & 8.33 & 1.52 \\
\cline { 2 - 7 } CI & $0-2$ & 2 & 6 & 9 & 7.50 & 2.12 \\
\hline Subtest 6 & hearing & 7 & 10 & 10 & 10.00 & 0.00 \\
\cline { 2 - 7 } CI & $4.1-7$ & 6 & 4 & 10 & 8.67 & 2.42 \\
\cline { 2 - 7 } CI & $2.1-4$ & 3 & 7 & 10 & 8.33 & 1.52 \\
CI & $0-2$ & 2 & 9 & 10 & 9.50 & 0.70 \\
\hline Score & hearing & 7 & 60 & 60 & 60.00 & 0.00 \\
\cline { 2 - 7 } CI & $4.1-7$ & 6 & 21 & 60 & 52.17 & 15.40 \\
\cline { 2 - 7 } CI & $2.1-4$ & 3 & 51 & 60 & 54.67 & 4.72 \\
\cline { 2 - 7 } CI & $0-2$ & 2 & 45 & 59 & 52.00 & 9.89 \\
\hline success \% & hearing & 7 & 100 & 100 & 100.00 & 0.00 \\
\cline { 2 - 6 } CI & $4.1-7$ & 6 & 35 & 100 & 86.94 & 25.67 \\
\cline { 2 - 6 } CI & $2.1-4$ & 3 & 85 & 100 & 91.11 & 7.87 \\
\cline { 2 - 6 } CI & $0-2$ & 2 & 75 & 98.33 & 86.66 & 16.49 \\
\hline
\end{tabular}

Table 5 shows the results of CI children aged between 7.1 and 10, and their hearing peers. In this age group, CI children were divided into three hearing age groups: from 0 to 2, from 2.1 to 4 , and from 4.1 to 7 . Equally as in the younger group, hearing children achieved maximum scores on all 6 subtests (10 points) and on the total score (60 points). Their achievement on TTI test was 100\% (Table 5).

CI children achieved maximum score on subtest 1 . Regardless of their hearing age they all achieved maximum score of 10 points, as their hearing peers. CI children with hearing age from 0 to 2 achieved maximum score on subtest 1 , and then on subtest 6 with the average score of 9.50 points (Table 5). Their worst result was on subtest 5 with the average score of 7.50. The total score of this group of CI children was 52 points, which is $86.66 \%$ of successfully completed tasks. CI children with hearing age from 2.1 to 4 achieved maximum score on subtests 1 and 2 (10 points), and the worst result on subtest 5 with 8.33 points. The average total score of this group of CI children was 54.67 points, which is $91.11 \%$. Children with the longest hearing age from 4.1 to 7 years achieved maximum score on subtest 1 , and then on subtest 2 with the average score of 8.83 points. Their worst result was on subtest 5 with the average score of 8.00 points. The results on test 5 probably require linguistic complexity and the need of a more complex cognitive processing of verbal instructions on this subtest. Verbal instructions on 
Đoković, S., Todorović, S.: Influence of hearing age and understanding verbal instructions in children with cochlear implants

this subtest are longer; they consist of 9 words, as opposed to previous subtests ranging from 3 to 6 words which require the engagement of short-term verbal memory. Also, a new category, i.e. a circle as a geometry shape, is introduced on this subtest. On this subtest, the children had a task to auditorily and then visually perceive and direct attention to the given objects, discriminate and recognize two requested concepts, discriminate and select two roles, engage short-term verbal memory and perform a certain task, which means they had to put the observed and recognized objects into a certain relation (Lift a yellow boat and put it in a red circle). On previous subtests, children had a similar task, however they did not put the objects into relations in the performing phase (Show a red boat and a blue plane). The total average score of this group of CI children was 52.17 points, which is $86.94 \%$ success on TTI test. There is a lower dispersal of results in this age group of $\mathrm{CI}$ children when compared to younger children. Minimum total score in $\mathrm{CI}$ children with hearing age from 4.1 to 7 was 21 and maximum 60, in CI children with hearing age from 2.1 to 4 minimum total score was 51 and maximum 60, and in CI children with hearing age from 0.1 to 2 minimum was 45 and maximum 59 (Table 5).

Table 6 - Results of understanding verbal instructions in hearing and CI children (aged between 7.1 and 10)

\begin{tabular}{lccc}
\hline & AM & F(2) & p \\
\hline Subtest 1 & 0.00 & $/$ & $/$ \\
\hline Subtest 2 & 2.37 & 1.31 & 0.310 \\
\hline Subtest 3 & 2.98 & 0.73 & 0.547 \\
\hline Subtest 4 & 4.75 & 0.71 & 0.561 \\
\hline Subtest 5 & 5.98 & 0.96 & 0.438 \\
\hline Subtest 6 & 2.87 & 1.16 & 0.358 \\
\hline Score & 234.77 & 78.25 & 0.502 \\
\hline
\end{tabular}

Table 6 shows comparative analysis results of understanding verbal instructions between CI children of different hearing age and hearing children (chronological age from 7.1 to 10). No statistically significant differences were determined on any of the subtests or the total score. This indicates that CI children of older chronological age catch up with the results of hearing children, regardless of the hearing age. If we observe hearing age as an isolated variable, based on the obtained results, it does not have the main influence on understanding verbal 
Specijalna edukacija i rehabilitacija (Beograd), Vol. 12, br. 3. 275-289, 2013.

instructions in CI children. This is also confirmed by the total scores on TTI test in CI children with different hearing age, which show that children with shorter hearing age achieve somewhat better results than children with longer hearing age (Table 5). Different results obtained during statistical analysis of younger and older CI children with different hearing age compared to hearing population lead to the conclusion that chronological age, i.e. maturation or some other rehabilitation factors influence the understanding of verbal instructions in CI children, and not only the length of using cochlear implant.

Table 7 - Differences between CI children (aged between 4 and 10) in understanding verbal instructions with regard to hearing age

\begin{tabular}{lccc}
\hline & $\mathrm{AM}$ & $\mathrm{F}(2)$ & $\mathrm{p}$ \\
\hline Subtest 1 & 17.503 & 1.605 & 0.237 \\
\hline Subtest 2 & 6.136 & .402 & 0.542 \\
\hline Subtest 3 & 29.103 & 1.536 & 0.247 \\
\hline Score & 145.336 & 1.302 & 0.283 \\
\hline
\end{tabular}

In order to once again check the obtained results, statistical analysis was performed within the group of CI children. For this analysis, CI children were divided into groups only according to hearing age, regardless of the chronological age. Data from first three subtests were processed, since all CI children from the sample did those subtests. Statistical analysis indicated that there are no statistically significant differences in understanding verbal instructions in $\mathrm{CI}$ children with regard to hearing age (table 7).

With regard to the influence of hearing age on understanding verbal instructions in CI children, the results of this research are opposite to some other studies, such as the research of Plant and Moor (1992) who determined that hearing and chronological age influence this speechlanguage level of CI children. However, the results of this research confirm some previously obtained findings, such as Dowell's results from 2002, which indicate that hearing age influences the perception and identification of phonemes and words, but not the perception and understanding of sentences. It is obvious that there are many contradictions in research results concerning the influence of hearing age on certain levels of auditory and speech-language development of CI children. This leads to the conclusion that it is necessary to develop a more precise methodological frame for this type of research. 
Đoković, S., Todorović, S.: Influence of hearing age and understanding verbal instructions in children with cochlear implants

\section{CONCLUSION}

The aim of this paper was to analyze the influence of hearing age on understanding verbal instructions in CI children, and to compare the achieved results to the results of hearing children. It can be concluded from the results that no obtained findings indicate that hearing age influences better understanding of verbal instructions. No statistically significant differences were determined by comparing the results of $C I$ children with regard to their hearing age $(p=0.283$ in the total score) (Table 7). Statistically significant differences were obtained in children with chronological age from 4 to 7 with regard to hearing children, regardless of hearing age. However, there were no statistically significant results in CI children with chronological age from 7.1 to 10 with regard to hearing children. This research indicates that chronological age has a greater influence on understanding verbal instructions than hearing age.

This could be explained by the fact that hearing age, defined as the length of using cochlear implant, is not enough for mastering complex language elements, such as understanding and performing certain verbal instructions. The length of using $C I$ ensures a continuous auditory stimulation, which influences the improvement of perceiving acoustic speech segments, but does not ensure learning complex lexical and grammatical relations within sentences. The influence of chronological age, indicated by research results, can be attributed to maturation aspects of child development, and also to longer periods of certain rehabilitation activities in these children. However, it should be emphasized that some authors, such as James, recommend a stricter methodological concept of studying the influence of hearing age on auditory and speech-language achievements in CI children with regard to hearing population, which is based on comparing these two groups not according to chronological, but according to hearing age. In other words, CI children with hearing age of 3 years are compared with three years old hearing children (James at al., 2007).

Great variability of the obtained results, observed in studying CI results, was also confirmed in this research. This indicates that apart from general factors known to influence the mastering of auditory and speech-language abilities in CI children, special attention should be 
Specijalna edukacija i rehabilitacija (Beograd), Vol. 12, br. 3. 275-289, 2013.

given to analyzing individual characteristics of successful CI children. Researches on learning, memory, attention, and cognitive strategies of processing language information, would certainly greatly contribute to explaining the causes of individual differences in $\mathrm{CI}$ results.

TTI test has proved to be an adequate instrument for the assessment of understanding verbal instructions in CI children. Thus, it should be used not only for determining the condition, but also for planning rehabilitation procedures with regard to understanding language. However, this test was completely inadequate for the analysis of understanding verbal instructions in hearing children.

\section{REFERENCES}

1. Beadle, E., A., McCInley, D., J., Nikolopoulos, T., P., Brough, J., O’Donoghue, G., M., Archbold, S.,M. (2005). Long-Term Functional Outcomes and Academic-Occupational Status in Implanted Children After 10 to 14 Years of Cochlear Implant Use. Otology \& Neurotology, 29, 1152-1160.

2. Connor, C., M., Craig, H., K., Raudenbush, S., W., Heavner, K., Zwolan, T., A. (2006). The age at which young deaf children receive cochlear implants and their vocabulary and speech production growth: Is there an added value for early implantation? Ear and Hearing, 27, 628-644.

3. Dowell, R., C., Shani, J., D., Dettman, P., Blamey, J., Barker, E., Graeme, M., C. (2002). Speech perception in children using cochlear implants: prediction of long-term outcomes. Cochlear Implants International, 3, 1-18.

4. Đoković, S., \& Ostojić, S. (2010). Specrographic analyusis of the fundamental voice in children with cochlear implants. In J. Kovačević, \& V. Vučinić (Eds.), Disabilities and Disorders: Phenomenology, Prevention and Treatment Part I, 49-65.

5. Eisenberg L.,S., Johnson, K., C., Martinez, A, S., DesJardin, J., L., Stika, C., J., Dzubak, D., Mahalak., L., Rector, E., P. (2008). Comprehensive Evaluation of a Child With an Auditory Brainstem Implant, Otology\&Neurotology, 29, 251-257. 
Đoković, S., Todorović, S.: Influence of hearing age and understanding verbal instructions in children with cochlear implants

6. Fryauf-Bertschy, H., Tyler, R., Kelsay, D., Gantz, B., Woodworth, G. (1997). Cochlear implant use by prelingually deafened children: the influence of age at implant and length of device use. Journal of Speech, Language and Hearing Research, 40, 183-199.

7. James, D., Rajput, K., Brinton, J., Usha, G. (2007). Phonological Awareness, Vocabulary, and Word Reading in Children Who Use Cochlear Implants: Does Age of Implantation Explain Individual Variability in Performance Outcomes and Growth?. Journal of Deaf Studies and Deaf Education, 13, 118-136.

8. CIrk, K.,I., Miyamoto, R.,T., Ying, E.,A., Perdew, A.,E., Zuganelis, H. (2002). Cochlear implantation in young children: effects of age at implantation and communication mode, Volta Review, 102(4), 127-144.

9. McConkey, A., R., Zimmerman-Phillips, S., Robbins, A., Osberger, J., Dawn Burton Koch, D., B., CIshon-Rabin, L.(2004). Effect of Age at Cochlear Implantation on Auditory SCIll Development in Infants and Toddlers, Archive Otolaryngology Head Neck Surgery, 130(5), 570-574.

10. Micić B., Arsović N., Mirić D., Ostojić S.(2008). Assessment Of Auditory Development During First Two Years By Littlears Questionnaire, In Verbal Communication Disorders, prevention, detection, treatment, IEFPG, 199-209.

11. Miyamoto, R.,T., Houston, D.,M., CIrk, K.,I., Perdew, A.,E., Svirsky, M.,A. (2003). Language Development in Deaf Infants Following Cochlear Implantation. Acta Oto-laryngologica, 123, 241-244.

12. Miyamoto, R.,T., CIrk, K.,I., Robbins, A., M., Todd, S., Riley, A. (1996). Speech Perception and Speech Production SCIlls of Children with Multichannel Cochlear Implants. Acta Oto-laryngologica, 116, 240-243.

13. Niparko, J., K., \& Blake, S., W. (1998). History of Cochlear Implants. Cochlear Implants: Principles and Practices. Lippincott Williiams \& WilCIns, Philadelphia.

14. Ostojić S., Đoković S., MiCIć B. (2007). Kohlearna inplantacijapregled istraživanja EARS baterije testova. Specijalna edukacija $i$ rehabilitacija, br. 3-4, 61-71. 
15. Ostojić, S., Đoković, S., Dimić, N., Micić, B. (2011). Kohlearni implantat - razvoj govora i jezika kod gluve i nagluve dece posle implantacije, Vojnosanitetski pregled, 68 (4), 349-352.

16. Pisoni, D.,B., Conway, C.,M., Kronenberger, W., Horn, D.,L., Karpicke, J., Henning, S. (2008). Efficacy and effectiveness of cochlear implants in deaf children. In: Marschark, M., Hauser, P., editors. Deaf Cognition: Foundations and Outcomes. New York: Oxford University Press, 52-101.

17. Plant, G., Moore, A. (1992). The Common Objects Token (COT) test: A sentence test for profoundly hearing impaired children, Australian Journal of Audiology, 14,76-83.

18. Svirsky, M.,A., Teoh, S.,W., Neuburger, H. (2004). Development of Language and Speech Perception in Congenitally, Profoundly Deaf Children as a Function of Age at Cochlear Implantation. Audiology\&Neurotology, 9, 224-233.

19. Uziel, A.,S., Sillon, M., Vieu, A., Artieres, F., Piron, J.,P., Daures, J.,P,, Mondain, M., (2007). Ten-year follow-up of a consecutive series of children with multichannel cochlear implants. Otology and Neurotology, 28(5), 615-28. 
Đoković, S., Todorović, S.: Influence of hearing age and understanding verbal instructions in children with cochlear implants

\title{
UTICAJ SLUŠNOG UZRASTA NA RAZUMEVANJE VERBALNIH NALOGA KOHLEARNO IMPLANTIRANE DECE
}

\author{
Sanja Đoković*, Selena Todorović** \\ Univerzitet u Beogradu - Fakultet za specijalnu edukaciju i rehabilitaciju* \\ Institut za eksperimentalnu fonetiku i patologiju govora**
}

\section{Sažetak}

Slušni uzrast se definiše kao vremenski period korišćenja amplifikacije. Većina istraživanja pokazuju da slušni uzrast utiče na brzinu formiranje slušnih i govorno-jezičkih sposobnosti gluve dece, naročito ako je kohlearna implantacija urađena pre treće godine života. Istraživanje je bilo usmereno na ispitivanje uticaja slušnog uzrasta na razumevanje verbalnih naloga kohlearno implantirane dece. Uzorkom je bilo obuhvaćeno 23 kohlearno implantirane dece i 21 dete urednog sluha uzrasta od 4 do 10 godina. Slušni uzrast kohlearno implantirane dece se kretao od 2 do 7 godina. Za ispitivanje razumevanja verbalnih naloga korišćen je Token test sa igračkama koji je adaptiran za decu oštećenog sluha. Analiza rezultata je pokazala da postoje statistički značajne razlike između kohlearno implantirane i čujuće dece na svim subtestovima i u ukupnom skoru na uzrastu od 4 do 7 godina bez obzira na slušni uzrast (subtest $1 \mathrm{p}<0,001$, subtest $2 \mathrm{p}<0,000$, subtest3 $\mathrm{p}<0,001$, ukupan skor $\mathrm{p}<0,000$ ), a na uzrastu od 7,1 do 10 godina statistički značajna razlika nije uočena ni na jednom subtestu takođe bez obzira na slušni uzrast. Komparativna analiza rezultata unutar eksperimentalne grupe između dece različitog slušnog uzrasta pokazala je da razlika između ove dve grupe u razumevanju verbalnih naloga nije statistički značajna.

Ključne reči: kohlearni implant, slušni uzrast, razumevanje

Primljeno: 28.6.2013.

Prihvaćeno:15.8.2013 